\title{
Study of phytoproteases stability in aqueous-organic biphasic systems using linear free energy relationships
}

\author{
Sonia Barberis ${ }^{\mathrm{a}, *}$, Evelina Quiroga $^{\mathrm{a}}$, Susana Morcelle ${ }^{\mathrm{b}}$, Nora Priolo ${ }^{\mathrm{b}}$, Juan M. Luco ${ }^{\mathrm{c}}$ \\ ${ }^{a}$ Laboratorio de Bromatología, Facultad de Química, Bioquímica y Farmacia, Universidad Nacional de San Luis, \\ Chacabuco y Pedernera, 5700 San Luis, Argentina \\ ${ }^{\mathrm{b}}$ LIPROVE, Laboratorio de Investigación de Proteínas Vegetales, Facultad de Ciencias Exactas, \\ Universidad Nacional de La Plata, 47 y 115, 1900 La Plata, Argentina \\ ${ }^{\mathrm{c}}$ Departamento de Química, Facultad de Química, Bioquímica y Farmacia, Universidad Nacional de San Luis, \\ Chacabuco y Pedernera, 5700 San Luis, Argentina
}

Received 2 October 2004; received in revised form 9 August 2005; accepted 21 November 2005

Available online 6 January 2006

\begin{abstract}
In this paper we study the effect of different water-immiscible organic solvents (benzene, toluene, 1-butanol, 1-octanol, dichloroethane, dichloromethane, diethyl ether, hexane, chlorobenzene, acetophenone, $n$-dodecane, trichloroethylene, ethyl acetate) on the stability (residual caseinolytic activity after $4 \mathrm{~h}$ ) of soluble phytoproteases, such as araujiain, funastrain and papain in aqueous-organic biphasic systems. Besides, the effect of organic solvents on enzymatic catalysis was quantitatively studied by means of linear free energy relationships (LFERs). The organic solvents were characterized by several physicochemical properties, and multiple linear regression analysis (MLRA) together with non-linear regression were the methods used to search the relationships between the residual caseinolytic activity data and several physicochemical parameters. Those enzymes show much greater activity and stability in some biphasic media than in water. On the other hand, all developed correlations represented highly significant LFERs models and showed that non-specific polar and hydrophobic factors are of prime and approximately equal importance for the biocatalytic activity of araujiain, funastrain and papain in the studied biphasic systems, while the specific polar interactions are of little importance for activity. The results suggested that araujiain, funastrain and papain do not suffer unfolding in the studied biphasic media and they are able to retain their native or native-like configurations, though with altered characteristics or properties. This fact was demonstrated by means of a comparative FTIR spectroscopy study in both, buffer and biphasic media, for each studied enzyme.
\end{abstract}

(C) 2005 Elsevier B.V. All rights reserved.

Keywords: Phytoproteases; Papain; Funastrain; Araujiain; Aqueous-organic biphasic systems; LFERs

\section{Introduction}

Most enzyme-catalyzed processes are carried out in aqueous solutions. However, many reaction products cannot be obtained in aqueous media for various reasons such as insolubility of substrates, unfavorable thermodynamic equilibrium and difficulties in the product recovery and enzyme inhibition by reagents and/or products. However, in many cases, these limitations can be overcome by performing the reactions in non-aqueous media. It is generally accepted that when enzymes are placed in organic media, they exhibit several advantages such as the shift

\footnotetext{
* Corresponding author. Tel.: +54 2652 424689; fax: +54 2652431301 .

E-mail address: sbarberi@unsl.edu.ar (S. Barberis).
}

in the thermodynamic equilibrium of the reaction in favor of product formation, enhanced thermostability and the possibility of manipulating the enantioselectivity, regioselectivity and chemoselectivity of enzyme-catalyzed reactions through appropriate choice of the solvent [1-4].

Because enzymes are usually insoluble in neat organic solvents, strong efforts have been made to solubilize them [5], such as chemical modifications using polyethylene glycol, alteration of the primary sequence of the enzyme or non-covalent modification using detergents [6-8]. Unfortunately, these approaches are limited because the systems are difficult to characterize, optimize and scale up, which are very important issues in the biotechnology industry.

In order to take full advantage of the benefits of non-aqueous enzymology, we have to understand the fundamental interactions 
between solvent and enzyme. An approach to understand the catalytic activity of enzymes in organic solvents is to use the socalled linear free energy relationships (LFERs) to describe quantitatively the solvents effects on enzymatic catalysis [9]. Thus, several solvent physical properties such as hydrophobicity measured as the octanol-water partition coefficient (commonly used in its logarithmic form), dielectric constant and dipole moment have all been used to predict the catalytic activity of enzymes [10-12]. However, the predictive power of such one-parameter LFERs is quite limited because not always a single-parameter is able to describe appropriately all the enzyme-solvent interactions to allow a quantitative description of the solvent effects on biocatalytic activity [13]. Therefore, it is not surprising that different enzymatic systems usually require different regression coefficients in such LFERs as has been demonstrated by a variety of applications in the field of non-aqueous enzymology [14,15].

In this report, a polyparameter LFERs approach was used to study the effect of different water-immiscible organic solvents (benzene, toluene, 1-butanol, 1-octanol, dichloroethane, dichloromethane, diethyl ether, hexane, chlorobenzene, acetophenone, $n$-dodecane, trichloroethylene, ethyl acetate) on the stability (residual caseinolytic activity after $4 \mathrm{~h}$ ) of soluble phytoproteases such as araujiain, funastrain and papain in aqueous-organic biphasic systems. The organic solvents were characterized by several physicochemical properties, and multiple linear regression analysis (MLRA) together with non-linear regression were the methods used to search the relationships between the residual caseinolytic activity data and several physicochemical parameters.

\section{Materials and methods}

\subsection{Materials}

Araujiain is the crude extract obtained from latex of fruits of Araujia hortorum Fourn. (Asclepiadaceae) [16,17]. Funastrain is the crude extract obtained from latex of stems of Funastrum clausum (Jacq.) Schlechter (Asclepiadaceae) gathered on $0.1 \mathrm{M}$ citric-phosphate buffer $\mathrm{pH} 6.5$ with $5 \mathrm{mM}$ EDTA and cysteine, centrifuged at $16,000 \times g$ for $30 \mathrm{~min}$ at $4{ }^{\circ} \mathrm{C}$ to discard insoluble materials and finally ultra centrifuged at $100,000 \times g$ for $60 \mathrm{~min}$ at $4{ }^{\circ} \mathrm{C}$. Commercial papain of Carica papaya L. (Caricaceae) (E.C.3.4.22.2, 30,000 USP/Umg) was supplied by E. Merck (Darmstadt, FRG).

\subsection{Caseinolytic activity measurement}

Proteolytic assays were performed using casein (Hammarsten type, Research Organics, Cleveland, OH, USA) as substrate. The reaction mixture was prepared by mixing $0.1 \mathrm{ml}$ of the enzyme sample with $1.1 \mathrm{ml}$ of $1 \%$ casein containing $12 \mathrm{mM}$ Cys, in a $0.1 \mathrm{M}$ Tris- $\mathrm{HCl}$ buffer (optimum $\mathrm{pH}$ for each enzyme). The reaction was carried out at $40^{\circ} \mathrm{C}$ and it was stopped $10 \mathrm{~min}$ later by the addition of $1.8 \mathrm{ml}$ of $5 \%$ trichloroacetic acid (TCA). Each test tube was centrifuged at $3000 \times g$ for $30 \mathrm{~min}$ and the absorbance of the supernatant was measured at $280 \mathrm{~nm}$. An arbitrary enzyme unit (caseinolytic unit, Ucas) was defined as the amount of protease, which produces an increment of one absorbance unit per min in the assay conditions [17]. The initial total content of proteins from crude extracts was determined according to Bradford method [18].

\subsection{Selection of organic solvents}

A statistical design was carried out by clustering 70 organic solvents according to their physicochemical properties (descriptors), which were extracted from the literature [19-28]. HPLCgrade organic solvents were purchased from Sigma (St. Louis, $\mathrm{MO}$ ).

Ten immiscible organic solvents which are representative of each group were chosen for the araujiain, funastrain and papain stability assays, covering a wide range of $\pi_{1}$ (solvent dipolarity/polarizability); $\alpha_{1}$ (solvent hydrogen-bond acid or acidity); $\beta_{1}$ (solvent hydrogen-bond base or basicity); $V_{\mathrm{m}}$ (molar volume); $\delta_{\mathrm{H}}^{2}$ (Hildebrand cohesive energy density), $\varepsilon$ (dielectric constant), $\eta_{25}$ (refraction index), $\mu$ (dipole moment), $E_{\mathrm{T}(30)}$ (Dimroth-Reichardt polarity indicator), $\log P_{\text {oct }}$ (logarithm of the partition coefficient in a standard octanol-water two-phase system), $S^{\prime}$ (Drago solvent polarity scale) and $\beta$ (dielectric parameter). Statistical calculations such as stepwise multiple regression and non-linear regression analyses were performed with Statgraphics Plus (5.0 version).

\subsection{Stability assays in aqueous-organic biphasic systems}

Enzyme solutions of araujiain and funastrain (lyophilized powder) containing $1 \mathrm{mg}$ (total content of proteins) $/ \mathrm{ml}$ were prepared for stability assays in 30:70, 50:50 and 70:30 ratios of $0.1 \mathrm{M}$ Tris- $\mathrm{HCl}$ buffer (optimum $\mathrm{pH}$ for each enzyme) and immiscible organic solvent. Each trial was performed by incubation of the mixture for $4 \mathrm{~h}$ at $40^{\circ} \mathrm{C}$, under controlled magnetic stirring. The aqueous phase was sampled at $4 \mathrm{~h}$ and residual caseinolytic activity was quantified. Variation coefficients $\left(\left(S_{\mathrm{d}}\right.\right.$ Mean $\left.\left.^{-1}\right) \times 100\right)$ of reported values were lower than $1.5 \%$ for activity assays; calculated in each case from triplicate results. Since araujiain and funastrain belong to the class of cysteine proteases, a comparison with papain under similar experimental conditions was also carried out.

\subsection{FTIR spectroscopy}

The infrared spectra were measured at $20^{\circ} \mathrm{C}$ with a Nicolet Protégé model 460 Fourier transform infrared spectrophotometer, provided with CsI beam splitter between 4000 and $225 \mathrm{~cm}^{-1}$. The spectral resolution was better than $2 \mathrm{~cm}^{-1}$ between 4000 and $2000 \mathrm{~cm}^{-1}$, and better than $1 \mathrm{~cm}^{-1}$ in the remaining ranks. Araujiain was incubated for $4 \mathrm{~h}$ in Tris- $\mathrm{HCl}$ buffer $(\mathrm{pH} 8)$, and in $50 \%(\mathrm{v} / \mathrm{v})$ hexane and $0.1 \mathrm{M}$ Tris $-\mathrm{HCl}$ buffer $(\mathrm{pH} 8)$. Afterwards, the samples were centrifuged in a low-speed centrifuge for $20 \mathrm{~min}$ and the pellet obtained was separated from the supernatant for its analysis. Approximately $0.5-1.0 \mathrm{mg}$ of dried protein was combined with $600 \mathrm{mg}$ of potassium bromide and ground into a fine powder. The powder was annealed into a disc using a hydraulic press. The correction of the basis line and the 
quantification was carried out using OMNIC spectrophotometer program.

\section{Results and discussion}

\subsection{Qualitative analysis of phytoproteases stability in aqueous-organic biphasic systems}

Although the presence of organic solvents may facilitate a catalytic process, as a rule these solvents tend to cause disruption of hydrogen bonds and of hydrophobic interactions as well as changes in the dynamics and conformation of the protein $[9,29]$.
Bearing this in mind, two-liquid phase systems were chosen to study the stability performance of araujiain, funastrain and papain in those media.

The comparison between the residual caseinolytic activity of araujiain, funastrain and papain in 30:70,50:50 and 70:30 ratios of $0.1 \mathrm{M}$ Tris- $\mathrm{HCl}$ buffer ( $\mathrm{pH} 8$ for araujiain and 8.5 for papain and funastrain) and different immiscible organic solvents, after $4 \mathrm{~h}$ of incubation at $40^{\circ} \mathrm{C}$, is shown in Fig. 1 . After a first inspection of this figure, it can be observed that the highest specific caseinolytic activity was retained by araujiain.

Araujiain caseinolytic activity profiles showed the highest retention (Ucas/mg protein) in a medium containing $50 \%(\mathrm{v} / \mathrm{v})$
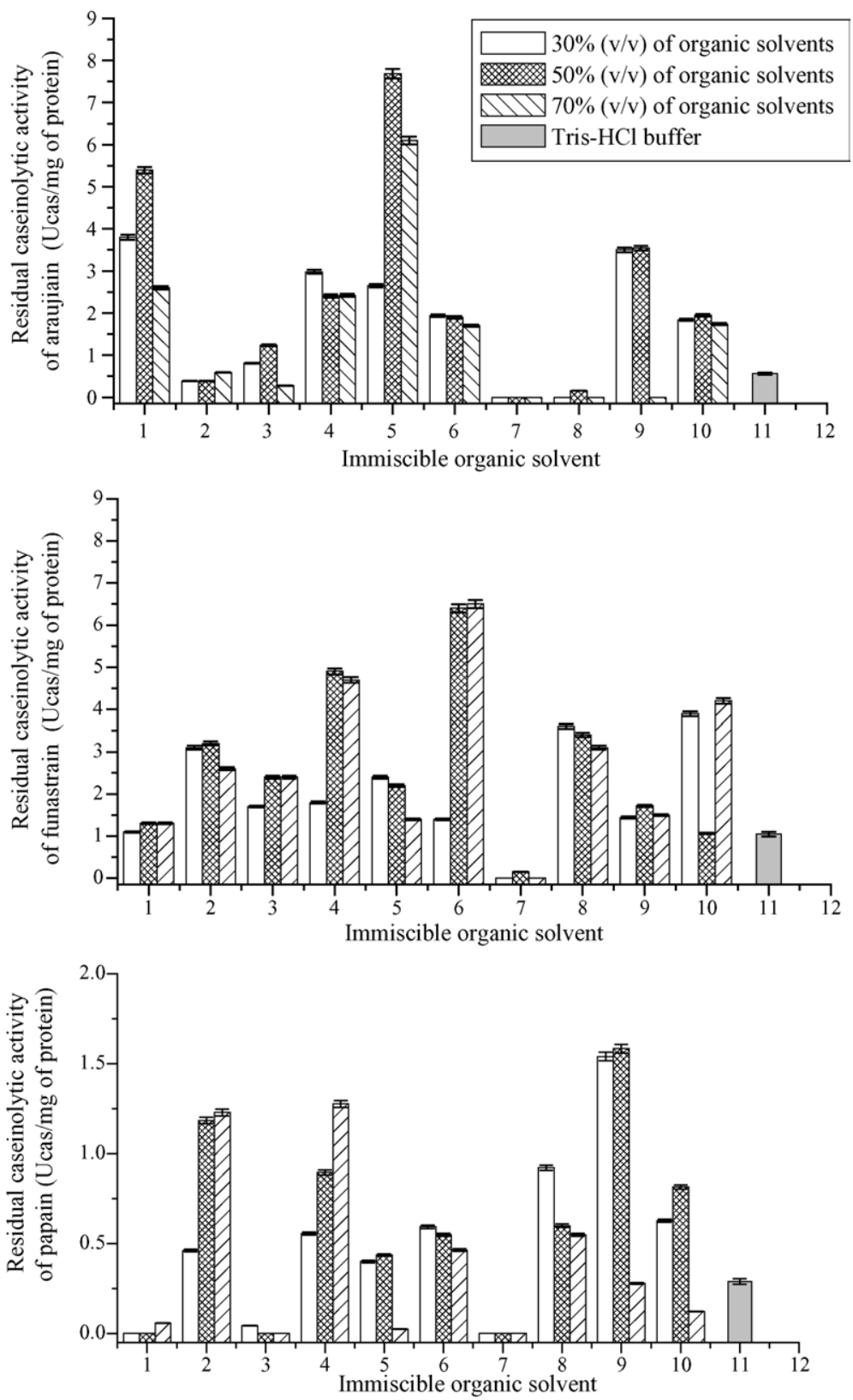

Fig. 1. Residual caseinolytic activity (Ucas/mg protein) of araujiain, funastrain and papain, in 30:70, 50:50 and 70:30 ratios of Tris- $\mathrm{HCl}$ buffer (optimum pH for each enzyme) and different immiscible organic solvents: 1, benzene or toluene; 2, 1-butanol or 1-octanol; 3, dichloroethane or dichloromethane; 4, diethyl ether; 5, hexane; 6, chlorobenzene; 7, acetophenone; 8, $n$-dodecane; 9, trichloroethylene; 10, ethyl acetate; 11 , Tris- $\mathrm{HCl}$ buffer (optimum pH for each enzyme), after $4 \mathrm{~h}$ of incubation at $40^{\circ} \mathrm{C}$ 
hexane and $0.1 \mathrm{M}$ Tris- $\mathrm{HCl}$ buffer $\mathrm{pH} 8$, after $4 \mathrm{~h}$ of incubation at $40^{\circ} \mathrm{C}$. Likewise, funastrain and papain caseinolytic activity profiles showed the highest retention (Ucas/mg protein) in media containing $70 \%(\mathrm{v} / \mathrm{v})$ chlorobenzene and $0.1 \mathrm{M}$ Tris $-\mathrm{HCl}$ buffer $\mathrm{pH} 8.5$ and $50 \%(\mathrm{v} / \mathrm{v})$ trichloroethylene and $0.1 \mathrm{M}$ Tris- $\mathrm{HCl}$ buffer $\mathrm{pH} 8.5$, respectively, after $4 \mathrm{~h}$ of incubation at $40^{\circ} \mathrm{C}$ (Fig. 1).

It is important to point out that residual caseinolytic activity of araujiain, funastrain and papain in aqueous media (0.1 M Tris- $\mathrm{HCl}$ buffer $\mathrm{pH} 8$ and 8.5$)$ was $0.560,1.045$ and $0.290 \mathrm{Ucas} / \mathrm{mg}$ protein, respectively, after $4 \mathrm{~h}$ of incubation at $40{ }^{\circ} \mathrm{C}$ (Fig. 1). These values were 90,85 and $80 \%$ lower than those obtained in a biphasic system containing $50 \%(\mathrm{v} / \mathrm{v})$ hexane, $70 \%(\mathrm{v} / \mathrm{v})$ chlorobenzene or $50 \%(\mathrm{v} / \mathrm{v})$ trichloroethylene, respectively, after $4 \mathrm{~h}$ of incubation at $40{ }^{\circ} \mathrm{C}$. In addition, the initial caseinolytic activities of those enzymes in water buffered solution were much lower than those values observed in the twophase media already mentioned. When comparing the initial and residual caseinolytic activities in water and two-phase media, a decrease of the autolysis degree was observed.

As the enzymes had been dissolved in an aqueous phase in studied biphasic media, a behavior similar to the one showed in a buffer solution was expected. However, the partition of the water-immiscible organic solvents into the aqueous phase reduced the autolysis degree and produced a considerable activation of the enzymes with the mentioned above organic solvents.

As will be discussed later, these results suggest that araujiain, funastrain and papain dissolved into the majority of the studied biphasic media do not suffer unfolding, and they are able to retain their native or native-like configurations, though with altered characteristics or properties. Nevertheless, in the presence of some exceptional immiscible organic solvents, like acetophenone, araujiain, funastrain and papain are inactivated (Fig. 1). The enzyme inactivation can be due to the toxicity of the organic solvent molecules dissolved in the aqueous phase (molecular toxicity) and/or the presence of a separate organic phase (phase toxicity) [30]. As the concentration of organic solvent dissolved in the aqueous phase was low to extremely low, the molecular toxicity must have had smaller effects on inactivation.
On the other hand, the amount of water associated with the enzyme is considered a key determinant of the properties (e.g. activity, stability, specificity) that it exhibits in non-aqueous media [31-36]. A general conclusion of the effect of water percentage in the mixture on the residual enzymatic activity was impossible to achieve in our trials because it depended on the organic solvent used in each particular case. Nevertheless, we think that changes in water availability are not relevant concerning what has happened in the studied system. Those enzymes had a substantial aqueous liquid phase in all cases, and the composition of the aqueous phase was almost independent of the relative volume of the organic phase used.

\subsection{LFERs analysis of phytoproteases stability in aqueous-organic biphasic systems}

Several authors have attempted to correlate and predict enzyme activity and/or stability in non-aqueous systems with certain solvent parameters such as dielectric constant, water solubility, Hildebrand solubility, three-dimensional solubility parameter space and $\log P_{\text {oct }}$. In practice, however, $\log P_{\text {oct }}$ values are still used as a good guidance for the purpose of solvent selection for biocatalysis [11,37-39]. Nevertheless, in this case, there is no straightforward correlation between $\log P_{\text {oct }}$ values and the behavior of some phytoproteases in the aqueous-organic biphasic systems under study. Further, as already mentioned, it does not seem likely that any single-parameter will provide us a clear relationship of all enzyme-solvent interactions to allow a quantitative description of the solvent effects on biocatalytic activity. Hence, to evaluate and to understand the effect of immiscible organic solvents on those enzymes, it was necessary to carry out an extensive polyparameter LFERs analysis. Because of the large number of physicochemical parameters in relation to the used stability data, a stepwise multiple regression procedure based on the forward-selection and backwardelimination methods was used for inclusion or rejection of parameters in the screened models. In order to avoid overestimations or difficulties in the interpretation of the resulting models, pairs of variables with a correlation coefficient $\geq 0.90$ were classified as intercorrelating ones, and only one of these

Table 1

Physicochemical parameter of the organic solvents

\begin{tabular}{|c|c|c|c|c|c|c|c|c|c|c|c|c|c|}
\hline Organic solvent & $\alpha_{1}$ & $\beta_{1}$ & $\pi^{*}$ & $\varepsilon$ & $\delta_{\mathrm{H}}^{2}$ & $\log P_{\mathrm{oct}}$ & $\mu$ & $E_{\mathrm{T}(30)}$ & $\eta_{25}$ & $\delta($ corr $)$ & $\beta$ & $S^{\prime}$ & $V_{\mathrm{m}}$ \\
\hline Hexane & 0.0 & 0.00 & 0.08 & 1.89 & 52.8 & 3.50 & 0.00 & 31.0 & 1.3722 & 0.0 & 0.00 & 0.68 & 131.30 \\
\hline Ciclohexane & 0.0 & 0.00 & 0.00 & 2.01 & 67.2 & 3.40 & 0.00 & 30.9 & 1.4235 & 0.0 & 0.00 & 1.11 & 108.90 \\
\hline Benzene & 0.0 & 0.10 & 0.59 & 2.28 & 83.8 & 2.00 & 0.00 & 34.3 & 1.4972 & 1.0 & 0.00 & 1.73 & 89.50 \\
\hline Chlorobenzene & 0.0 & 0.07 & 0.71 & 5.69 & 93.6 & 2.90 & 1.72 & 36.8 & 1.5221 & 1.0 & 7.82 & 1.98 & 102.30 \\
\hline Diethyl ether & 0.0 & 0.47 & 0.27 & 4.3 & 56.2 & 0.85 & 1.11 & 34.5 & 1.3496 & 0.0 & 3.80 & 1.73 & 104.70 \\
\hline Dichloromethane & 0.3 & 0.00 & 0.82 & 8.93 & 97.7 & 1.25 & 1.60 & 40.7 & 1.4212 & 0.5 & 11.54 & 2.08 & 64.40 \\
\hline Dichloroethane & 0.0 & 0.00 & 0.81 & 10.4 & 98.3 & 2.50 & 1.36 & 41.3 & 1.4425 & 0.5 & 12.68 & 2.10 & 79.40 \\
\hline$n$-Dodecane & 0.0 & 0.00 & 0.03 & 2.01 & 59.7 & 6.60 & 0.07 & 31.1 & 1.4151 & 0.0 & 0.00 & 0.90 & 228.60 \\
\hline Trichloroethylene & 0.0 & 0.00 & 0.53 & 3.42 & 84.8 & 2.40 & 0.90 & 35.9 & 1.4556 & 0.5 & 2.22 & 1.90 & 90.10 \\
\hline Ethyl acetate & 0.0 & 0.45 & 0.55 & 5.98 & 79.2 & 0.70 & 1.78 & 38.1 & 1.3704 & 0.0 & 10.38 & 2.15 & 98.50 \\
\hline 1-Butanol & 0.8 & 0.88 & 0.47 & 17.8 & 129.5 & 0.80 & 1.66 & 49.7 & 1.3949 & 0.0 & 10.04 & 2.74 & 92.00 \\
\hline 1-Octanol & 0.6 & 0.97 & 0.37 & 9.86 & 103.3 & 2.90 & 1.76 & 48.1 & 1.4229 & 0.0 & 5.24 & 0.80 & 158.00 \\
\hline Toluene & 0.0 & 0.11 & 0.54 & 2.4 & 79.4 & 2.73 & 0.38 & 33.9 & 1.4936 & 1.0 & 0.25 & 1.66 & 106.60 \\
\hline Acetophenone & 0.0 & 0.49 & 0.90 & 17.4 & 103.7 & 1.80 & 3.05 & 40.6 & 1.5321 & 0.0 & 22.45 & 2.52 & 117.40 \\
\hline
\end{tabular}


was included in the screened model. Table 1 lists the physicochemical parameters included in the analysis of enzymes under study.

\subsubsection{Araujiain stability in aqueous-organic biphasic systems}

Stepwise multiple regression analysis of residual caseinolytic activity (Ucas/mg protein) of araujiain for 30:70, 50:50 and 70:30 organic-aqueous ratios against all parameters shown in Table 1 yielded the following equations:

$$
\begin{aligned}
& y(30 \%)=5.597(0.522)-0.694(0.135) \varepsilon+0.0225(0.006) \varepsilon^{2} \\
& -0.098(0.012) \log P_{\mathrm{oct}}^{2} \text {, } \\
& R^{2}=0.949, r=0.974, \mathrm{rcv}=0.950, s=0.395 \text {, } \\
& n=10, F=37.33 \\
& y(50 \%)=\underset{(0.000)}{10.63(1.010)}-0.954(0.277) \varepsilon+0.0392(0.011) \varepsilon^{2} \\
& -2.181(0.774) S^{\prime} \\
& \text { (0.037) } \\
& R^{2}=0.956, r=0.977, \mathrm{rcv}=0.827, s=0.659 \text {, } \\
& n=9, F=35.81
\end{aligned}
$$

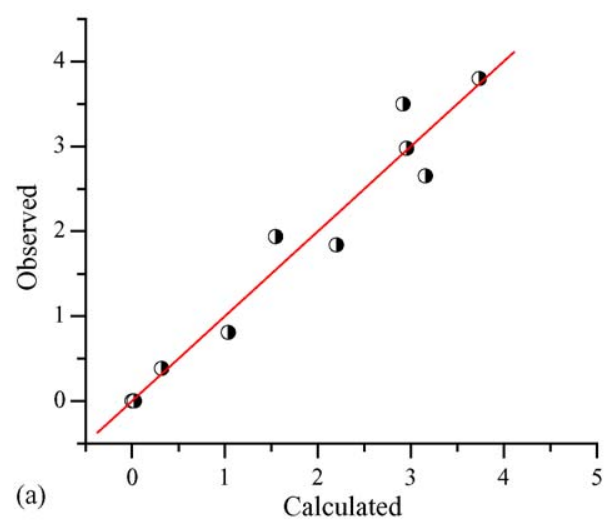

$y(70 \%)=8.597(0.922)+3.047(1.008) \beta_{1}-3.966(0.540) S^{\prime}$, $(0.000)$ (0.023)

$(0.000)$

$R^{2}=0.908, r=0.953, \mathrm{rcv}=0.902, s=0.674$,

$n=9, F=29.73$

In these and the following equations, $n$ is the number of averaged stability data used in each regression analysis, $s$ the standard deviation, $R^{2}$ the squared correlation coefficient, $r$ the correlation coefficient and $F$ is the Fisher $F$-statistic. The figures in parentheses are the standard deviations and $P$-values of coefficients and $y$ is the residual caseinolytic activity (Ucas/mg protein). The rcv is the cross-validation coefficient which describes the predictive power of derived models. Intercorrelation between the pairs of selected descriptors is acceptable, $\varepsilon$ versus $S^{\prime}(r=0.63)$, $\varepsilon$ versus $\log P_{\text {oct }}(r=-0.459)$ and $S^{\prime}$ versus $\beta_{1}(r=0.15)$, which is important to reach a correct physicochemical interpretation of the equations obtained. The agreement between the observed and calculated $y$ values for each of the derived equations is satisfactory, as shown in Fig. 2.

It should be noted that the stability data for $n$-dodecane was not included in Eqs. (2) and (3). In the case of Eq. (2), although a lower but significant fit is obtained when $\left(\log P_{\text {oct }}\right)^{2}$ and $S^{\prime}$ are the parameters used $(r=0.90, s=1.2$ and $n=10)$, the point corresponding to $n$-dodecane has a large influence on regression equation. On the other hand, the analysis of $y(70 \%)$ system

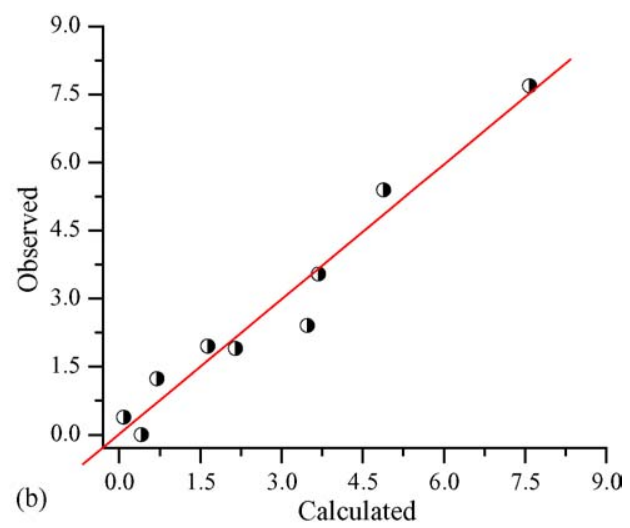

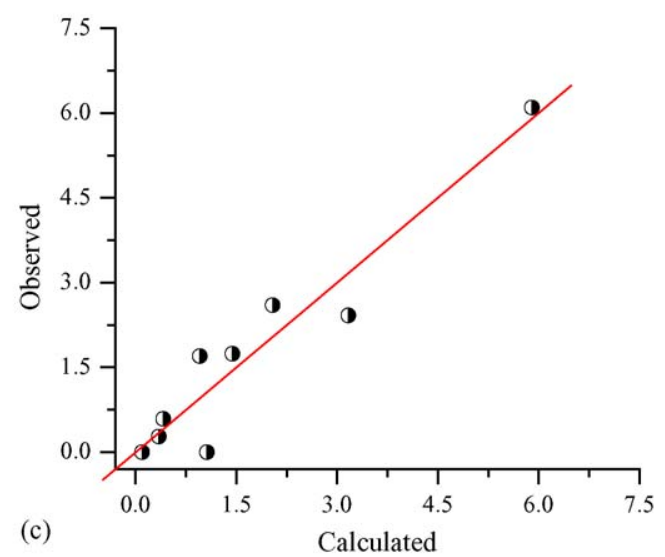

Fig. 2. Relationships between the experimental and calculated residual caseinolytic activity (Ucas/mg protein) values for araujiain in (a) 30:70; (b) 50:50; (c) 70:30 ratios of different immiscible organic solvents and Tris- $\mathrm{HCl}$ buffer $(\mathrm{pH} 8)$, after $4 \mathrm{~h}$ of incubation at $40^{\circ} \mathrm{C}$. 
shows that none of the parameters used in this study can account for the complete loss of activity that results from the use of $n$ dodecane as solvent. However, considering the $\log P_{\text {oct }}$ range of solvents included in the analysis, it is probable that the strong hydrophobic character of $n$-dodecane is the responsible for the inactivation of araujiain, although this fact cannot be expressed in the form of a regression equation for the 50:50 and 70:30 (v/v) $n$-dodecane-aqueous systems. In general, the evaluation of the parameter weights of Eqs. (1) and (2) shows that a decrease of the residual caseinolytic activity (Ucas/mg protein) of araujiain will be obtained by increasing the solvent dielectric constant $(\varepsilon)$. This can be illustrated by the following non-linear regression equation:

$$
\begin{aligned}
& y(50 \%)=\underset{(0.000)}{16.848(1.228) \varepsilon^{-1.228(0.076)}}(0.000) \\
& R^{2}=0.987, r=0.993, s=0.296, n=9, F=566.24
\end{aligned}
$$

The statistical characteristics of Eq. (4) are better than those of Eq. (2), as indicated by the standard deviation, correlation coefficient and $F$-test, and the data fitting are displayed in Fig. 3. However, qualitatively Eqs. (1), (2) and (4) are similar in that a decrease in the solvent dielectric constant enhances residual caseinolytic activity whereas an increase in the hydrophobicity or the non-specific solvation interactions as reflected by $\log P_{\text {oct }}$ and $S^{\prime}$, respectively, has the opposite effect. On the other hand, on analyzing Eq. (3), the dependence of $y(70 \%)$ system on the solvent basicity $\left(\beta_{1}\right)$ can be observed; that is, an increase in the ability of solvents to act like hydrogenbonding acceptors will generally result in a greater caseinolytic activity.

In summary, all the equations obtained are highly significant statistically and even though the number of data-points used in the models was small, the high $R^{2}$ and rcv values provide confidence that the results obtained are not artifactual. On the other hand, analyzing them from a structural point of view, it is clear that both non-specific $\left(\log P_{\text {oct }}, \varepsilon, S^{\prime}\right)$ and specific

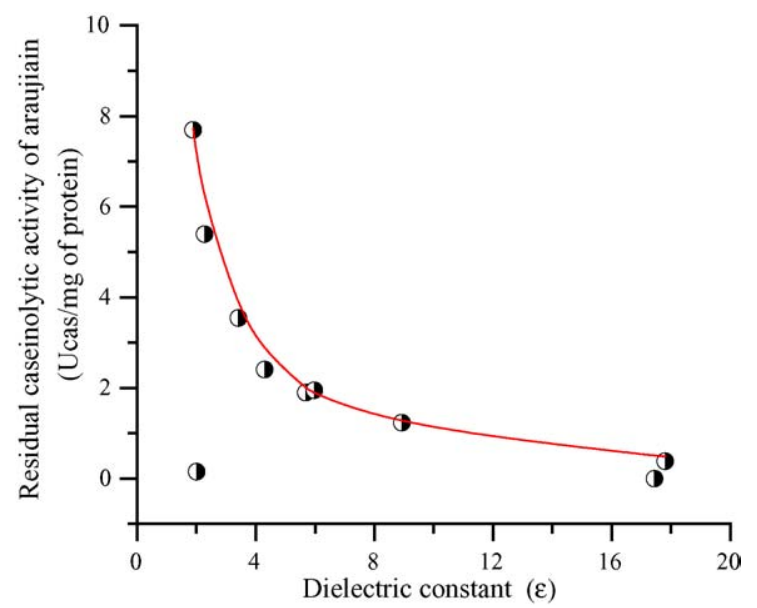

Fig. 3. Residual caseinolytic activity (Ucas/mg protein) of araujiain in a 50:50 ratio of Tris- $\mathrm{HCl}$ buffer $(\mathrm{pH} 8)$ and different immiscible organic solvents, after $4 \mathrm{~h}$ of incubation at $40^{\circ} \mathrm{C}$ vs. dielectric constant $(\varepsilon)$. $\left(\beta_{1}\right)$ enzyme-solvent interactions are important in governing the residual caseinolytic activity of araujiain in these systems. The former arise from electrostatic forces including polarization forces between the solvent and the enzyme, whereas the latter comprises acceptor hydrogen-bonding interactions.

\subsubsection{Funastrain stability in aqueous-organic biphasic} systems

Stepwise multiple regression analysis of residual caseinolytic activity (Ucas/mg protein) of funastrain in 30, 50 and 70\% (v/v) biphasic systems against all physicochemical parameters shown in Table 1 did not yield any statistically significant multiparameter equation. Nevertheless, after some experimentation, it becomes apparent that there are some significant non-linear relationships between the $\log P_{\text {oct }}$ and $\beta$ variables and the residual caseinolytic activity of funastrain. The most meaningful nonlinear regression equations found were:

$$
\begin{aligned}
& y(30 \%)=-2.912(0.827)+2.544(0.435) \log P_{\mathrm{oct}}^{0.5} \\
& +2.211(0.323) / \log P_{\mathrm{oct}}^{2}, \quad R^{2}=0.887, \\
& (0.000) \\
& r=0.942, s=0.399, n=9, F=23.54 \\
& y(50 \%)=8.245(2.402) / \\
& \text { (0.011) } \\
& \left\{1+\underset{(0.000)}{\left.[\beta-6.144(0.371) / 2.857(0.836)]^{2}\right\}},\right. \\
& R^{2}=0.734, r=0.857, s=1.095, n=10, F=9.68 \\
& y(70 \%)=7.301(1.399) / \\
& \text { (0.01) } \\
& \left\{1+\underset{(0.000)}{\left.[\beta-6.598(0.405) / 3.384(0.711)]^{2}\right\}},\right. \\
& R^{2}=0.813, r=0.902, s=0.941, n=10, F=15.27
\end{aligned}
$$

The statistical quality of Eqs. (5)-(7) is good and accounts for $88.8,73.4$ and $81.3 \%$ of the variance in the data, respectively. For the three equations, plots of observed activities versus $\log P_{\text {oct }}$ and $\beta$ values are shown by Fig. 4 . As shown by Eq. (5) and Fig. 4a, a clear non-linear hydrophobicity-activity relationship is observed in the form of an unsymmetrical curve with more or less linear descending and ascending sides of the relationship. The evaluation of $\log P_{\text {oct }}$ weights for this equation suggests that the residual caseinolytic activity of funastrain in this biphasic system will be very low in solvents having a $\log P_{\text {oct }}$ value between 1.5 and 2.5 , whereas in hydrophobic $\left(\log P_{\text {oct }}>3\right)$ or hydrophilic $\left(\log P_{\text {oct }}=0.7-1.5\right)$ solvents such as $n$-dodecane or ethyl acetate, the activity observed will be generally high. It should be noted that the activity data for acetofenone were omitted from this equation $(n=9)$ since a lower level of statistical significance is obtained when this data-point is used to derive Eq. (5). However, an interesting point to highlight is that, according to the obtained relationship between $y(30 \%)$ and $\log P_{\text {oct }}$, the enzymatic inactivation produced by this solvent is not sur- 

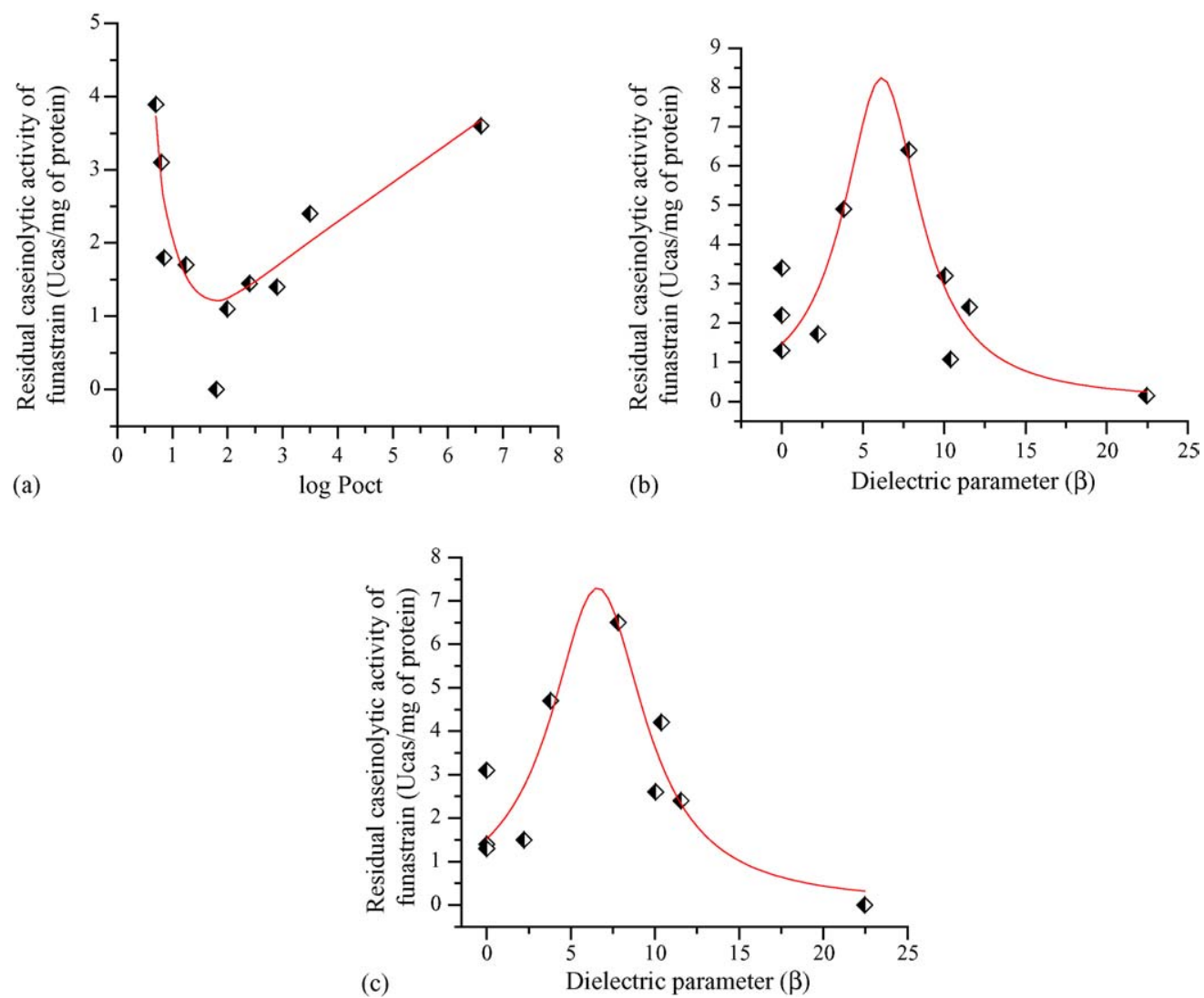

Fig. 4. Residual caseinolytic activity (Ucas/mg protein) values for funastrain in (a) 30:70; (b) 50:50; (c) 70:30 ratios of different immiscible organic solvents and Tris- $\mathrm{HCl}$ buffer $(\mathrm{pH} 8.5)$, after $4 \mathrm{~h}$ of incubation at $40^{\circ} \mathrm{C}$ vs. $\log P_{\text {oct }}$ and dielectric parameter $(\beta)$ values.

prising since their $\log P_{\mathrm{oct}}$ value is 1.8 (see Table 1 ), which lies in the range of lower residual caseinolytic activity for this system.

On the other hand, analyzing Eqs. (6) and (7) (see Fig. 4b and c) there is a non-linear dependence between the solvent polarity, as shown by the dielectric $\beta$ parameter, and the residual activity of funastrain for these 50 and $70 \%(\mathrm{v} / \mathrm{v})$ biphasic systems. The $\beta$ parameter, which is based on Onsager's electrostatic solvation theory, is proportional to the ratio of squared dipole moment and molar volume of solvent $\left(\mu^{2} / V_{\mathrm{m}}\right)$ [27]. This composite parameter, referred to as the dipole density function, can be associated conceptually to the charge density of ionic species. Thus, this function describes the influence of solvent molar volume on dipole moment of a given magnitude of solvent solvation. On the basis of the $\beta$ weights in both equations and the plots shown in Fig. $4 \mathrm{~b}$ and c, solvents having a $\beta$ value between 4 and 8 might exhibit a high residual activity in these systems. In summary, the correlations shown above including the $\log P_{\text {oct }}$ and $\beta$ parameters support the idea that hydrophobic and non-specific polar enzyme-solvent interactions are of prime importance for the biocatalytic activity of funastrain in the studied biphasic systems.

\subsubsection{Papain stability in aqueous-organic biphasic systems}

After some considerations, linear and non-linear regression analysis of residual caseinolytic activity (Ucas/mg protein) of papain for each of the biphasic systems under study yielded the following equations:

$$
\begin{aligned}
& y(30 \%)=-0.034(0.103)-0.115(0.016) \varepsilon+0.481(0.078) \mu \\
& \begin{array}{lll}
(0.565) & (0.000) & (0.002)
\end{array} \\
& +0.0052(0.0007) V_{\mathrm{m}} \text {, } \\
& (0.000) \\
& R^{2}=0.951, r=0.975, \mathrm{rcv}=0.923, s=0.090, \\
& n=9, F=37.33 \\
& y(50 \%)=\underset{(0.000)}{0.419(0.043)}-\underset{(0.000)}{2.004(0.122) \pi_{1}^{3}} \\
& +0.586(0.045) / \mu^{0.5}, \\
& (0.000) \\
& R^{2}=0.978, r=0.989, s=0.072, n=9, F=139.11 \\
& y(70 \%)=\underset{(0.000)}{1.488(0.242) /}
\end{aligned}
$$

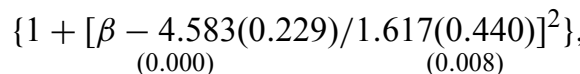

$$
\begin{aligned}
& R^{2}=0.880, r=0.938, s=0.192, n=10, F=25.75
\end{aligned}
$$

All the equations obtained are highly significant statistically and account for 95,98 and $88 \%$ of the variance in the data, respectively. In the preliminary analysis of the obtained models, a strong outlier (trichloroethylene) was detected and 


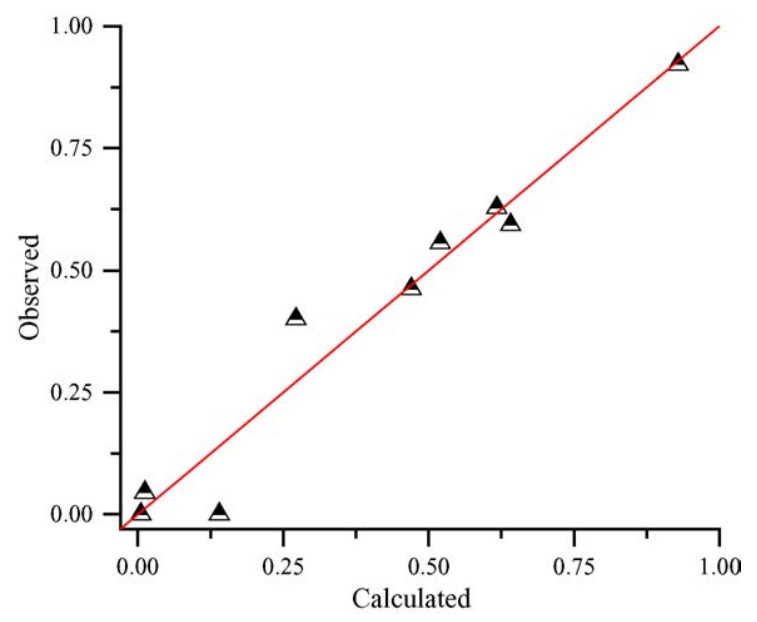

Fig. 5. Relationships between the experimental and calculated residual caseinolytic activity (Ucas/mg protein) values for papain in a 30:70 ratio of different immiscible organic solvents and Tris- $\mathrm{HCl}$ buffer ( $\mathrm{pH} 8.5$ ), after $4 \mathrm{~h}$ of incubation at $40^{\circ} \mathrm{C}$.

removed from Eqs. (8) and (9). None of the physicochemical parameters used in this study can account for the observed residual caseinolytic activity values in the 30:70 and 50:50 (v/v) trichloroethylene-buffer systems. The reason for this is not evident, especially taking into account that this data-point was well predicted by Eq. (10). Thus, this may be due to the intervention of specific factors not explained by the parameters considered in this study.

Fig. 5 shows the plot of activities observed in $30 \%(\mathrm{v} / \mathrm{v})$ organic-aqueous systems versus those calculated by Eq. (8). As can be seen in this figure, agreement between the measured and calculated data is very good. Taking into account the solvents parameters included in this correlation (the molar volume $\left(V_{\mathrm{m}}\right)$, the dielectric constant $(\varepsilon)$ and the dipole moment $(\mu)$ ), Eq. (8) concentrates information basically related to the influence of the dispersive and non-specific polar enzyme-solvent interactions on the residual caseinolytic activity under study.

On the other hand, Fig. 6 shows the three-dimensional plot of observed activity in the $50 \%(\mathrm{v} / \mathrm{v})$ organic-aqueous systems versus the dipolarity/polarizability and dipole moment solvent parameters as well as the corresponding response surface obtained from Eq. (9). As can be observed from this equation, the polarity effects $\left(\pi_{1}, \mu\right)$ on the residual caseinolytic activity of papain are non-linear, and the inspection of the parameter weights suggests that a greater activity will result from a compromise between the solvent-enzyme polarization forces (as reflected by the $\pi_{1}$ term) and the solvent-enzyme electrostatics interactions (as expressed by the $\mu$ term). Further, as shown in Fig. 6, solvents having values of $\mu$ and $\pi_{1}$ over the range of 1.5-2 and 0.3-0.6, respectively, might exhibit a high residual activity in these systems. These conclusions, of course, are valid only within the limitations of the present data set.

Finally, as can be observed from Eq. (10), there is a non-linear dependence between the dielectric $\beta$ parameter and the residual activity of papain for the $70 \%(\mathrm{v} / \mathrm{v})$ organic-aqueous systems. The statistical evaluation of Eq. (10) is satisfactory, especially as it includes the trichloroethylene data-point. As can be observed

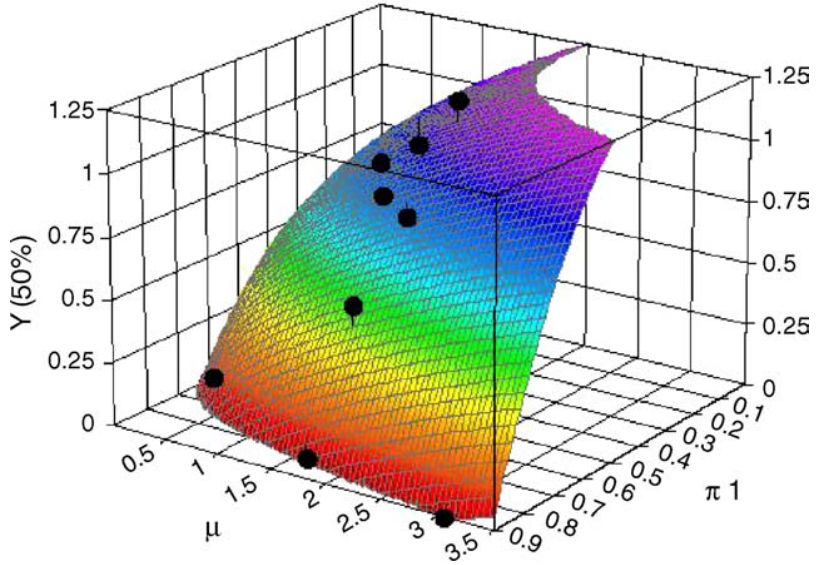

Fig. 6. Three-dimensional plot of observed activity for papain in a 50:50 ratio of Tris- $\mathrm{HCl}$ buffer $(\mathrm{pH} \mathrm{8.5)}$ and different immiscible organic solvents, after $4 \mathrm{~h}$ of incubation at $40{ }^{\circ} \mathrm{C}$ vs. the dipolarity/polarizability $\left(\pi_{1}\right)$ and dipole moment $(\mu)$ solvent parameters.

from Fig. 7, solvents having a $\beta$ value between 3 and 6 will exhibit a high residual activity in these systems.

On the other hand, from a structural point of view, the results obtained suggest that araujiain, funastrain and papain do not suffer unfolding in the studied biphasic media, and they are able to retain their native or native-like configurations, though with altered characteristics or properties. In order to demonstrate this fact, a comparative FTIR spectroscopic study was performed in both, buffer and some biphasic media for each of the studied enzymes. As an example, Fig. 8 shows araujiain FTIR spectra in buffer and in $50 \%(\mathrm{v} / \mathrm{v})$ hexane-buffer. According to this figure, maximum absorbance of amide I band of araujiain in buffer and $50 \%(\mathrm{v} / \mathrm{v})$ hexane-buffer were $1653 \mathrm{~cm}^{-1}$ (random band) and $1660 \mathrm{~cm}^{-1}$ ( $\alpha$-helix band), respectively. In addition, araujiain in buffer shows two $\beta$-sheet bands at $1635 \mathrm{~cm}^{-1}$, with the shoulder at $1640 \mathrm{~cm}^{-1}$ and $1698 \mathrm{~cm}^{-1}$, which were higher than in $50 \%(\mathrm{v} / \mathrm{v})$ hexane-buffer. Larger amounts of antiparallel $\beta$ sheet residues indicated the formation of tight intermolecular hydrogen bonds and larger quantities of enzymatic aggregates

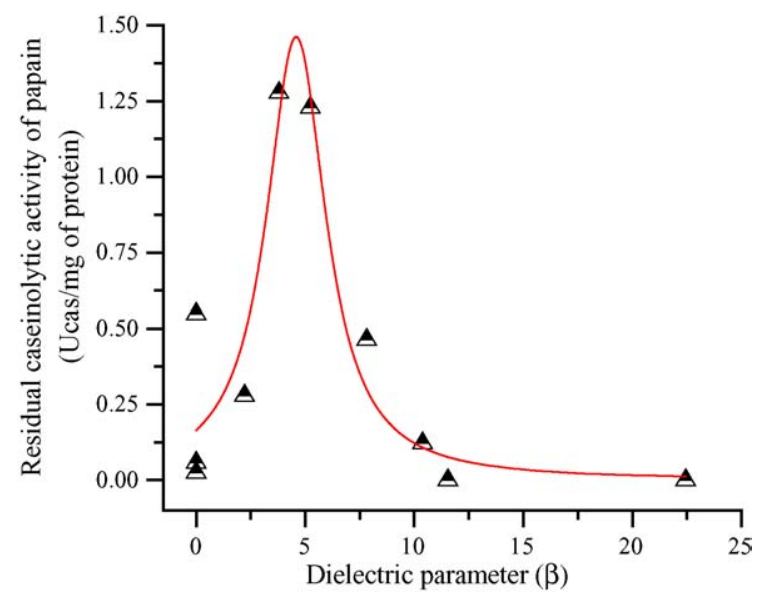

Fig. 7. Residual caseinolytic activity (Ucas/mg protein) values for papain in a 70:30 ratio of different immiscible organic solvents and Tris- $\mathrm{HCl}$ buffer $(\mathrm{pH}$ $8.5)$, after $4 \mathrm{~h}$ of incubation at $40^{\circ} \mathrm{C}$ vs. dielectric parameter $(\beta)$ values. 


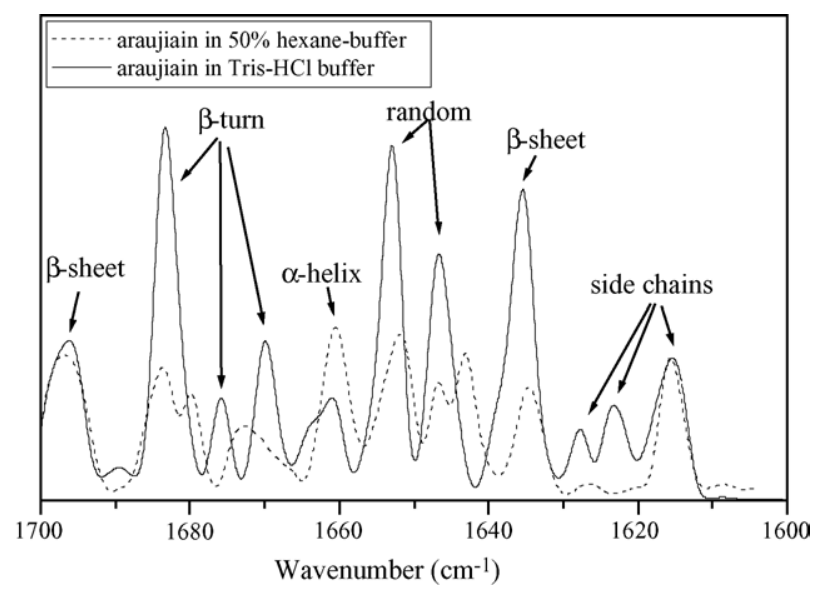

Fig. 8. Curve fitted inverted second-derivative infrared spectra of araujiain in $0.1 \mathrm{M}$ Tris- $\mathrm{HCl}$ buffer ( $\mathrm{pH} 8)$ and $50 \%$ hexane-buffer, at $25^{\circ} \mathrm{C}$.

in buffer than in the hexane-buffer. Thus, taking into account the information provided by Eq. (2), we think that the electrostatic forces including polarization forces $\left(\varepsilon\right.$ and $\left.S^{\prime}\right)$, which maintain the native secondary and tertiary structures of enzyme, are modified in this biphasic media, and the enzyme adopted a native-like conformation but with increased activity and stability. Similar results were also obtained for the other studied enzymes.

\section{Conclusions}

In this work, we have found some aqueous-organic biphasic media in which araujiain, funastrain and papain show much greater activity and stability than in buffered water and therefore, they can be useful for the enzymatic peptide synthesis.

Since any single-parameter approach is limited in its ability to reflect the possible enzyme-solvent interactions, a polyparameter LFERs approach was a powerful tool for predicting residual caseinolytic activity of araujiain, funastrain and papain in aqueous-organic biphasic media. Hence, all developed correlations represented highly significant LFERs models and showed that non-specific polar and hydrophobic factors are of prime and approximately equal importance for the biocatalytic activity of araujiain, funastrain and papain in the studied biphasic systems, while the specific polar interactions are of little importance for activity.

Finally, it is important to emphasize that the correlations obtained between the physicochemical parameters analyzed and the stability of araujiain, funastrain and papain in biphasic systems do not allow the prediction of the effect of organic solvents on other enzymes since each biocatalyst has to be studied individually.

\section{Acknowledgements}

S. Morcelle and E. Quiroga are CONICET fellows. The present work was supported by grants from CYTED, CIC, ANPCyT, Universidad Nacional de San Luis and Universidad Nacional de La Plata, Argentina.

\section{References}

[1] M.T. Barros, M.G.V. Carvalho, F.A.P. García, E.M.V. Pires, Biotechnol. Lett. 14 (1992) 179.

[2] S.E. Barberis, A. Illanes, in: The General Secretariat of the Organization of American States (Ed.), Enzyme Biotechnology, Biology Serie, Monography No. 35, Washington, DC, 1994, p. 225.

[3] G. Carrea, S. Riva, Angew. Chem. Int. Ed. 39 (2000) 2226.

[4] A.M. Klibanov, Nature 409 (2001) 241.

[5] P. Aldercreutz, in: A.M.P. Koskinen, A.M. Klibanov (Eds.), Enzymatic Reaction in Organic Media, Blackie Academic and Professional, London, 1996, p. 9

[6] K. Yoshinaga, H. Ishida, T. Sagawa, K. Ohkubo, in: J.M. Harris (Ed.), Poly(ethylene glycol) Chemistry: Biotechnical and Biomedical Applications, Plenum Press, New York, 1992, p. 103.

[7] B.A. Law, in: T. Godfrey, S. West (Eds.), Industrial Enzymes, Mac Millan, London, 1996, p. 387.

[8] J.D. Meyer, B.S. Kendrick, J.E. Matsuura, J.A. Ruth, P.N.M. Manning, Int. J. Pept. Protein Res. 47 (1996) 177.

[9] Z. Yang, A.J. Russell, in: A.M.P. Koskinen, A.M. Klibanov (Eds.), Enzymatic Reaction in Organic Media, Blackie Academic and Professional, London, 1996, p. 43.

[10] A.P. Fitzpatrick, A.M. Klibanov, J. Am. Chem. Soc. 113 (1991) 3166.

[11] L.V. Schneider, Biotechnol. Bioeng. 37 (1991) 627.

[12] C.R. Wescott, A.M. Klibanov, Biochim. Biophys. Acta 1206 (1994) 1.

[13] C. Laane, S. Boeren, R. Hilhorst, C. Veeger, in: C. Laane, J. Tramper, M.D. Lilly (Eds.), Biocatalysis in Organic Media, Elsevier Science Publishers B.V., Amsterdam, 1986, p. 65.

[14] A.K. Chaudhary, S.V. Kamat, E.J. Beckman, D. Nurok, R.M. Kleyle, P. Hajdu, A.J. Russell, J. Am. Chem. Soc. 118 (1996) 12891.

[15] D. Nurok, R.M. Kleyle, B.B. Muhoberac, M.C. Frost, P. Hajdu, D.H. Robertson, S.V. Kamat, A.J. Russell, J. Mol. Catal. B: Enzymatic 7 (1999) 273.

[16] W. Obregón, M.C. Arribére, S. Morcelle del Valle, C. Liggieri, N.O. Caffini, N.S. Priolo, J. Protein Chem. 20 (2001) 317.

[17] N. Priolo, S. Morcelle del Valle, M.C. Arribére, L. López, N.O. Caffini, J. Protein Chem. 19 (2000) 39.

[18] M.M. Bradford, Anal. Biochem. 72 (1976) 246

[19] M.H. Abraham, P.L. Grellier, Can. J. Chem. 66 (1988) 2673.

[20] M.H. Abraham, W.R. Lieb, N.P. Franks, J. Pharm. Sci. 80 (1991) 719.

[21] http://www.chemie.uni.marburg.de/ak39/et_hom_e.html, ET(30) Values.

[22] C. Reichardt, Chem. Rev. 94 (1994) 2319.

[23] J.M.L. Abboud, R. Notario, Pure Appl. Chem. 71 (1999) 645.

[24] http://sul-server-2.stanford.edu/byauth/burke/solpar, Solubility Parameters: Theory and Application, John Burke, 1984.

[25] M.H. Abraham, J.C. Mc Gowan, Chromatographia 23 (1987) 243.

[26] L.M. Russell, S. Drago, D.E. Richardson, J. Chem. Soc. Perkin Trans. 2 (1998) 159

[27] M. Dutkiewicz, J. Chem. Soc. Faraday Trans. 86 (1990) 2237.

[28] J. Zou, Q. Yu, Z. Shang, J. Chem. Soc. Perkin Trans. 2 (2001) 1439.

[29] J.S. Dordick, Enzyme Microb. Technol. 11 (1989) 194.

[30] Z. Yang, A.J. Russell, in: A.M.P. Koskinen, A.M. Klibanov (Eds.), Enzymatic Reactions in Organic Media, Chapman \& Hall, London, 1996, p. 42.

[31] A. Zaks, A.M. Klibanov, J. Biol. Chem. 263 (1988) 8017.

[32] L. Yang, J.S. Dordick, S. Garder, Biophys. J. 87 (2004) 812

[33] R. Affleck, Z.F. Xu, V. Suzawa, K. Focht, D.S. Clark, J.S. Dordick, Proc. Natl. Acad. Sci. U.S.A. 89 (1992) 1100.

[34] D.B. Volkin, A. Staubli, R. Langer, A.M. Klibanov, Biotechnol. Bioeng. 37 (1991) 843.

[35] W. Kauzmann, Adv. Protein Chem. 14 (1959) 1.

[36] P.J. Halling, Phil. Trans. R. Soc. Lond. B 359 (2004) 1287.

[37] C. Laane, S. Boeren, K. Vos, C. Veeger, Biotechnol. Bioeng. 30 (1987) 81.

[38] M. Reslow, P. Adlercreutz, B. Mattiasson, Appl. Microbiol. Biotechnol. 26 (1987) 1.

[39] Y.L. Khmelnitsky, V.V. Mozahev, A.B. Belova, M.V. Sergeeva, K. Martinek, Eur. J. Biochem. (1991) 19831. 